\title{
Belge Yönetiminde Kurumsal Koşulların Değerlendirilmesi: Türkiye Kızılay Derneği Örneği*
}

\section{Evaluation of Institutional Conditions in Records Management: The Example of Red Crescent Society}

\author{
Hande Uzun KÜLCÜ** ve Özgür KÜLCÜ***
}

\section{Öz}

Çalışma kapsamında kurumsal belge işlemlerini etkileyen koşulları ve sorunları tespit etmek amacıyla anket yapılmıştır. Anket çalışması Türkiye Kızılay Derneği (TKD) genel merkez birimleri ile bağlı birimlerde belge işlemlerine yönelik özgün koşulları tanımlayabilmek için gerçekleştirilmiştir.

Çalışmanın hipotezi “Türkiye Kızılay Derneği’nde belge yönetimi uygulamaları kurumda yapılacak kapasite değerlendirme çalışması ile geliştirilebilir" şeklinde belirlenmiştir. Gerçekleştirilen anket TKD içerisinde personel eğitiminde, belge erişime dönük üst veri unsurlarının tanımlanmasında, erişim kısıtlamaları, değerlendirme ve imha işlemlerinde, denetim mekanizmalarının oluşturulmasında, uygulamaların birimlere yayılmasında sorunlar yaşandığını, iletişim ve rutin yazışmalarda elektronik ortama geçişin öncelikli alanlardan olduğunu göstermiştir. Araştırma sonucunda, belgelerle çalışan TKD personeli kapasite değerlendirme çalışması ile kurumun belge sisteminin geliştirilebileceğine \%96,7 oranında destek vermiş, analizler sonucunda da kurumun belge yönetim programında sorunlar yaşandığı ortaya çıkmış ve hipotezimiz kanıtlanmıştır.

Anahtar sözcükler: Belge yönetimi, Kapasite değerlendirme, Türkiye Kızılay Derneği

\begin{abstract}
In order to identify the conditions and problems of institutional records management upon the example of Turkish Red Crescent Society, surveys were carried out both at the headquarters and branches, to examine the general hypothesis: "Records management applications might be elaborated by means of capacity evaluation attempts". Survey results had shown that $96.7 \%$ of the personnel shared the fundamental opinion behind
\end{abstract}

\footnotetext{
Çalışmada yer alan veriler, Hacettepe Üniversitesi Sosyal Bilimler Enstitüsü'nde 2008 yılında tamamlanan, "Belge Yönetiminde Kapasite Değerlendirme" adlı yüksek lisans tezinden elde edilmiştir. " Uzm. Türkiye Kızılay Derneği Haberleşme ve Arşiv Müdürlüğü, Ankara (handeu@kizilay.org.tr)

"** Yrd. Doç. Dr.; Hacettepe Üniversitesi Edebiyat Fakültesi Bilgi ve Belge Yönetimi Bölümü, Beytepe Ankara (kulcu@hacettepe.edu.tr)
} 
the hypothesis. Moreover, the analysis of the results had indicated that the institution experiences difficulties with its the records management system. The difficulties had been observed to arise especially in personnel training, defining metadata for accessing records, restrictions to access, evaluation and annihilation processes, establishing supervision, broadening the applications and the transition into the electronic communications media.

Keywords: Records management, Capacity assessment, Turkish Red Crescent Society

\section{Giriş}

Kurumlarda belgeler resmi iletişimi ve kurum içi bilgi alış verişini sağlayan, geriye dönük uygulamalara ışık tutan, idari - yasal denetim ve doğrulama uygulamaları için kanıt niteliği taşıyan, yönetimin kararları için gerekli bilgiyi bulunduran, içeriği ve form yapıları önceden belirlenmiş dokümanter kaynaklardır. Bu kaynakların etkin yönetimi sıralanan uygulamalarda başarı için gerekli görülmektedir (Cisco, 1999, s.172; Dollar, 2002, s.22; Penn, Mordel ve Pennix 1994, s.5; Shepherd, 2003, s. 13).

Kurumların idari sistemleri içerisinde tanımlanan belge yönetimi uygulamalarında başarı için, kurum içerisinde idari yapı ve belge uygulamalarına yönelik var olan kapasitenin analiz edilmesi gerekmektedir. Kurumlarda belge yönetimi uygulamalarına yönelik bir durum saptaması yapmaya dönük gerçekleştirilecek analizlerde, analiz ölçütleri doğru belirlenmek durumundadır. Bu kapsamda belge işlemlerini etkileme kapasitesine sahip, kurumsal ve ulusal koşullar ile uluslararası düzenlemeler ve standartlar göz önünde bulundurulmalıdır (Information Management Planning, 2005, ss.1-74; Shepherd, 2003, s.xii-xiii; William, 2002, s.6). Kurumlarda belge yönetimi uygulamaları geliştirilirken kurumun bağlı olduğu tüm birim ve bölümlerde belge işlemlerinin, sorunların ve beklentilerin tanımlanması, bağlı olunan yasal çevre ve ilgili alanda geliştirilen yol gösterici nitelikteki düzenlemeler incelenmesi gerekmektedir (Pember, 2006, s. 22; Shepherd, 2003, ss.30-31; Spratt, 2004: 8; Zawiyah ve Chell, 2002. s.55).

Ülkemizde belge yönetiminde program geliştirmeye dönük, Başbakanlık Devlet Arşivleri Genel Müdürlüğü (DAGM)'nün çeşitli kurumlarda gerçekleştirdiği analizler ve yayın faaliyetleri ile birkaç kurumda gerçekleştirilen uygulamalarla sınırı olan çalışmalar (Ayıklama ve İmha Komisyonlarına Ait Çalışma Rehber, 1996; Devlet Arşiv Hizmetleri Hakkında Yönetmelik, 1988; Devlet Arşiv Hizmetleri Hakkında Yönetmelikte Değişiklik Yapılmasına Dair Yönetmelik, 2001), özellikle 2000'li yıllarla birlikte artış göstermiştir. Bu noktada Bilgi Edinme Kanunu, Elektronik İmza Kanunu ile Başbakanlıkça geliştirilen Standart Dosya Planının etkili olduğu düşünülmektedir (Bilgi Edinme Hakkı Kanunu, 2003; Elektronik İmza Kanunu, 2004; Standart Dosya Planı, 2005).

Ülkemizde özellikle 90'lı yıllarla birlikte bağımsız olarak belge yönetimi alanına dönük kuramsal çalışmalar ağırlığını hissettirmeye başlamıştır (Gürbüz, 1990; İçimsoy, 1997; Kandur, 1998; Özdemirci 1996), 2000'li yıllarla birlikte ise belge yönetimi 
unsurları üzerine ve belge yönetimi ile farklı alanların ilişkilendirildiği çalışmalar gerçekleştirilmiştir (Çiçek, 2000; Külcü, 2005; Odabaş, 2007). 2000'li yıllarla bilgi teknolojilerinin çalışmalarda yoğunluğunu hissettirmeye başlaması Devlet Planlama Teşkilatı'nda da gerek komisyon çalışmaları gerekse kalkınma planları kapsamında çalışmaların yürütülmesine zemin hazırlamıştır (T.C. Başbakanlık Devlet Planlama Teşkilatı, 2008).

Ülkemizde belge yönetimi alanında yakın tarihte gerçekleştirilen önemli bir çalışma, Marmara Üniversitesi ve DAGM'nün birlikte yürüttüğü bir proje kapsamında 2005 yılında hazırlanan ve gözden geçirilmiş ikinci baskısı 2006 tarihinde basılan Elektronik Belge Yönetimi Sistem Kriterleri Referans Modeli (EBYSKRM)'dir (Kandur, 2006). Türk Standartları Enstitüsü (TSE) EBYSKRM'yi 19 Haziran 2007 tarihinde TSE 13298 koduyla "Bilgi ve dokümantasyon - Elektronik belge yönetimi" adıyla bir standart olarak kabul etmiştir (Türk Standartları Enstitüsü, 2007a/b). Yine TSE 1997 yılında uluslararası belge yönetimi standardı ISO 15489'u Türk Standardı olarak kabul etmiş ve TS ISO 15489-1-standart ve TSE ISO/TR 15489-2-kılavuz olarak yayımlanmıştır (TS ISO 15489-1,2007; TS ISO 15489-2, 2007).

\section{Metodoloji}

Kurumlarda belge işlemlerinin kurumsal gereksinimler, ulusal ve uluslararası düzenlemeler çerçevesinde, alanında eğitimli personel tarafından, birimler arasında uyumlu ve koordineli biçimde yürütülemiyor olması önemli bir sorun olarak görülmektedir. Bu sorunun önemli bir nedeni olarak, kurumlarda belge işlemlerine yönelik programlar oluşturulurken, var olan kapasiteyi değerlendirmeye dönük çalışmaların yapılmaması görülmektedir.

Bu çerçevede çalışmanın hipotezi "Türkiye Kızılay Derneği'nde belge yönetimi uygulamalarının geliştirilebilmesi için kapasite değerlendirme çalışmasının yapılmasına gereksinim vardır" biçiminde tanımlanmıştır.

Araştırmada, hipotezde belirlenen unsurlara ilişkin mevcut durumu tanımlayabilmek için, "betimleme yöntemi" kullanılmıştır. Betimleme yöntemi ile "olayların, objelerin, varlıkların, kurumların, grupların ve çeşitli alanların ne olduğu betimlenmeye, açıklanmaya çalışıımaktadır" (Kaptan, 1989: 34).

Çalışmanın alanını, TKD yönetim ve koordinasyon hizmetlerini yürüten Merkez Teşkilatına bağlı 22 birim ile ülkenin dört bir yanına yayılmış şubeleri, kan merkezleri, lojistik ve Afet Müdahale Yardımlar Yönetimi (AFOM) birimleri ile Afyon Mineralli Su İşletmesi (Afyon MSí) oluşturmaktadır.

TKD'de görevli toplam 2454 personelin önemli bir bölümü (anket verileri doğrultusunda 679 personel) günlük çalışmalarda belge işlemlerini gerçekleştirmekte ya da yoğun biçimde belgelerle işi olmaktadır. 
Anket kapsamında 19 Genel Merkez birimi (Basın Tanıtım, ERP Koordinatörlüğü, Gayrimenkul Yönetimi, Gençlik ve Gönüllülük, Haberleşme ve Arşiv Müdürlüğü, İnsan Kaynakları Müdürlüğü, Kan Hizmetleri Müdürlüğü, Kurumsal Gelişim, Eğitim Müdürlüğü, Mali İşler Müdürlüğü, Mali Kontrol Şubesi, Sağlık Hizmetleri Yönetimi, Satın Alma Müdürlüğü, Savunma Uzmanlığı, Şube Hizmetleri Müdürlüğü, Teftiş Kurulu Başkanlığı, Uluslararası İlişkiler, Yapı Teknik, Yönetim Hizmetleri), 16 kan merkezi, 11 lojistik birimi ve AFOM birimleri, 89 şube ve bağlı birim ile Afyon MSi olmak üzere beş grup altında toplanabilecek birimlerden sağlanan anket formları değerlendirmeye alınmıştır.

Tablo 1. TKD İçerisinde Gerçekleştirilen Anketin Gruplara Dağılımı

\begin{tabular}{lcc}
\hline & Sayı & $\%$ \\
\hline Genel Müdürlük & 165 & 24,3 \\
Kan Merkezleri & 228 & 33,6 \\
Lojistikler ve AFOM & 78 & 11,5 \\
Şubeler ve Bağlı Birimler & 198 & 29,2 \\
Afyon MSi & 10 & 1,5 \\
\hline Toplam & 679 & 100,0 \\
\hline
\end{tabular}

Anket çalışmasını ilgili birimlerde belge işlemlerini gerçekleştiren ya da kullanıcı olarak belge ve arşivlerden yararlanan tüm kişilerin doldurması için Genel Müdürlük tarafından bir tamim ${ }^{* * * *}$ çıkartılmıştır. Anket formlarının çoğaltılması ve Türkiye çapında ilgili tüm birimlere dağıtılması ve toplanması işlemlerini TKD Genel Müdürlüğü üstlenmiştir. Anket uygulaması 8 Ekim-9 Kasım 2007 tarihleri arasında gerçekleştirilmiştir.

TKD içerisinde tanımlanan hiyerarşik yapı ve hizmet alanları dikkate alınarak oluşturulan beş grup arasında verilen yanıtlardaki farklılıkları tespit etmek amacıyla karşılaştırma tabloları (crosstabs) oluşturulmuş ve "Khi Kare" değerleri hesaplanmıştır. Khi Kare değerlerinde eşik olarak kabul edilen 0,05'den küçük değerler gruplar arasında anlamlı bir çelişki olduğunu, üstündeki değerler ise anlamlı bir çelişki olmadığını göstermektedir (Baş, 2001, s.141).

\section{TKD Birimlerinde Personel Sayısı ve Belge Üretimi}

Tablo 2'de TKD genel merkez birimleri, şubeler, kan merkezleri, lojistik ve diğer birimlerde; toplam personel sayısı, belge işlemlerini yürüten ya da bu işlemlerden sorumlu personel sayısı, bir yılda birimden gönderilen ve birime gelen belge sayısına ilişkin betimsel istatistikler yer almaktadır.

Türkiye Kızılay Derneği Genel Müdürlüğünün 8.10.2007 tarihli 246 numaralı Genel Merkez ve 17.10.2007 tarihli 42 numaralı şube tamimleri. 
Anket verilerinin analizi sonucu TKD içerisinde Genel Müdürlük birimlerinde en yoğun personel AFOM (164 kişi) bünyesinde yer almaktadır. Ardından İnsan Kaynakları (99 kişi), Teftiş Kurulu Başkanlığı (27 kişi) ve yönetim hizmetleri (24 kişi) sıralanmaktadır. Belge ve arşiv personeli sayısında da AFOM (80 kişi), sağlık hizmetleri yönetimi (10 kişi) ve insan kaynakları (10 kişi) sıralanmaktadır.

Tablo 2. TKD Birimlerinde Personel Sayısı ve Belge Üretimi

\begin{tabular}{|c|c|c|c|c|}
\hline Birimin Adı & $\begin{array}{l}\text { Toplam } \\
\text { Personel } \\
\end{array}$ & $\begin{array}{l}\text { Belge/Arşiv } \\
\text { Personeli }\end{array}$ & Gelen Evrak & $\begin{array}{l}\text { Giden } \\
\text { Evrak }\end{array}$ \\
\hline \multicolumn{5}{|l|}{ Genel Müdürlük Birimleri } \\
\hline AFOM & 164 & 80 & 528 & 168 \\
\hline Basın Tanıtım & 10 & 1 & 530 & 680 \\
\hline Eğitim & 16 & 3 & 553 & 713 \\
\hline ERP Koordinatörlüğg̈ü & 10 & 1 & 125 & 475 \\
\hline Gayrimenkul Yönetimi & 11 & 1 & 2.236 & 3.140 \\
\hline Gençlik ve Gönüllülük & 10 & 1 & 2.217 & 967 \\
\hline Haberleşme ve Arşiv & 12 & 5 & 27.984 & 18.700 \\
\hline İnsan Kaynakları & 99 & 10 & 14.230 & 13.469 \\
\hline Kan Hizmetleri & 22 & 1 & 3.968 & 2.955 \\
\hline Kurumsal Gelişim & 22 & 1 & 1.106 & 817 \\
\hline Mali İşler & 22 & 0 & 11.505 & 1.292 \\
\hline Mali Kontrol & 14 & 1 & 1.391 & 1.335 \\
\hline Sağlık Hizmetleri Yönetim & 14 & 10 & 1.749 & 1.602 \\
\hline Satın Alma & 11 & 1 & 4.273 & 3.129 \\
\hline Savunma Uzmanlığı & 2 & 1 & 350 & 80 \\
\hline Şube Hizmetleri & 9 & 2 & 1.896 & 1.780 \\
\hline Teftiş Kurulu Başkanlığı & 26 & 3 & 1.193 & 591 \\
\hline Uluslararası İlişkiler & 7 & 2 & 239 & 931 \\
\hline Yapı Teknik & 18 & 1 & 1.150 & 1.200 \\
\hline Yönetim Hizmetleri & 24 & 1 & 3.014 & 2.599 \\
\hline Toplam & 499 & 125 & 80.237 & 56.623 \\
\hline Şubeler & 924 & 67 & 15.834 & 25.234 \\
\hline Kan Merkezleri & 705 & 42 & 8.771 & 12.164 \\
\hline Lojistik Merkezleri & 195 & 22 & 8.824 & 6.269 \\
\hline Afyon MSi & 107 & 1 & 1.615 & 2.727 \\
\hline Genel Toplam & 2.454 & 258 & 115.281 & 103.017 \\
\hline
\end{tabular}


TKD içerisinde gelen evrak sayısının en yoğun olduğu birim Haberleşme ve Arşiv Müdürlüğü'dür (27.984). Ardından sırasıyla İnsan Kaynakları (14.230) ve Mali İşler (11.505) gelmektedir. Giden belge sayısında yine Haberleşme ve Arşiv Müdürlüğü (18.700) ile İnsan Kaynakları (13.469) ilk iki sırada yer almaktadır. Gayrimenkul Yönetimi (3.140) ve Satın Alma (3.129) 3. ve 4. Sırada, giden evrak sayısında Yönetim Hizmetleri 5. sırada (2.599) bulunmaktadır.

\section{Personelinin Kurumda Çalışma Süresi}

Yapılan analizler TKD personelinin çalışma süresinin ağırlıklı olarak beş yıldan daha az olduğunu göstermektedir (Genel $\sum 2,014$ ). Aritmetik ortalama değerlerine göre TKD içerisinde en genç personel profili kan merkezlerinde çıkarken $\left(\sum 1,864\right)$, yaş ortalaması en yüksek grubu Genel Müdürlük $\left(\sum 2,286\right)$ oluşturmaktadır. Yüzdelik değerler incelendiğinde kan merkezlerinde çalışanların yarıdan fazlası (\%51,3'ü) kurum içerisinde beş yıldan daha az süredir çalıştığını dile getirirken, Lojistik ve AFOM'da en yüksek oran \%39,7 ile 6-10 yıl arasıdır. Genel Müdürlükte 11-20 yıl arası çalışanların oranı \%28, 10 yıldan az çalışanların oranı ise \%63,9'u bulmaktadır. 21 yıldan çok çalışanlar \%7,2 iken 11-20 yıl çalışanların oranı \% 28,5'dir.

\section{Deneklerin Belge ve Arşiv İşlemlerine Yönelik Sorumluluğu}

Analizler neticesinde ankete katılan deneklerin çoğunluğunun $(\% 91,5)$ belge ürettiği ve belge dosyalama işlemlerini yaptığı ya da ilgili alanda yönetici sorumluluğuna sahip olduğu saptanmıştır $(\% 91,5)$. Katılımcıların \%69'u belge dosyalama işlemlerini yürüttüklerini, \%54'ü belge ürettiklerini, \%37'si arşiv çalışmalarını da yürüttüklerini ve \%36'sı da belge işlemlerinin koordinasyonundan sorumlu olduklarını belirtmişlerdir. Soruya yanıt veren 679 personelin yalnızca \%8,5'i belge işlemlerine yönelik herhangi bir sorumluluk taşımadıklarını dile getirmişlerdir.

\section{Deneklerin Belge İşlemleri Kapsamındaki Eğitim Durumu}

Genel olarak değerlendirildiğinde belge işlemlerinde görevli personelin yarıdan fazlasının belge işlemlerine yönelik herhangi bir eğitim almadığı ortaya çıkmaktadır. Yürüttükleri ya da sorumlu oldukları belge işlemlerini "kendi çabalarımla öğrendim" diyen deneklerin oranı \%57,3 iken, ilgili konuda "herhangi bir bilgim yok" diyen deneklerin oranı \%21,7 çıkabilmektedir. Belge işlemlerinde herhangi bir sorumluluğu bulunmadığını dile getiren yaklaşık \%8,5'lik kesim dışında, bu işlemleri yürütenlerin yaklaşık \%12'lik kesimi yürüttükleri işlemler konusunda bilgisinin olmadığını dile getirmektedir. Ankete yanıt veren 658 personelden belge işlemlerine yönelik eğitim alanların oranı $\% 17,5$ 'de kalırken, ilgili okuldan mezun olduğunu dile getirenlerin oranı $\% 2,6$ 'dır. 


\section{Belge İşlemlerine Yönelik Günlük Harcanan Süre}

Personelin belge işlemlerine yönelik harcadığı süreye ilişkin betimsel istatistikler, soruyu yanıtlayan 660 personelin \%38,9'unun günde 2 ile 4 saat arasında, \%35,5'inin ise günde 5 saatten çok belge işlemleriyle uğraştıklarını göstermektedir. Günlük çalışmalarında belge işlemlerinin 1 saatten az yer tuttuğunu dile getirenlerin oranı \%17'de kalırken, 30 dakikadan az belge işlemleriyle uğraşanların oranı yalnız \%6,8 çıkmıştır. Ankete yanıt veren personelin sadece \%1,8'i günlük çalışmalarında belge işlemleriyle işlerinin olmadığını dile getirmişlerdir.

\section{Belge Üretim ya da Kullanım Nedenleri}

Anket deneklerinin günlük çalışmalarında belge üretim ya da kullanım nedenleri açısından betimsel istatistikleri şöyledir:

Ankete katılan denekler en çok (\% 82,5) görev tanımı içerisinde yer alan iş ve işlemlerin yürütülmesi için belge ürettiklerini ya da kullandıklarını dile getirmişlerdir. Ardından deneklerin önemli bir bölümü (\%70,6'sı) kurumda herhangi bir birime bilgi verme ya da bilgi alma nedeniyle, $\% 26,1$ 'i ise yönetim hizmetlerinin bir parçası olarak ya da denetim amacıyla belge ürettiklerini veya kullandıklarını belirtmişlerdir. Kurum dışından diğer kişi ya da kuruluşlarla yazışmalar amacıyla belge işlemleriyle ilgilenenlerin oranı da \%8,8'dir. Bu oranlar kurumda yürütülmekte olan belge işlemlerinin yaklaşık \%90'inin kurum içi belge işlemlerinden, \%10'dan azının ise kurum dışı belge işlemlerinden oluştuğunu ve bu durumun aynı oranda personelin belge işlemlerine dönük mesailerine de yansıdığını göstermektedir. Yukarıdaki şıklardan herhangi birini işaretleyerek ilgili alanda çalışmalara katıldığını dile getiren deneklerin oranı ise $\% 98,2$ 'yi bulmaktadır.

\section{Belge İşlemleri Yürütülürken Kullanılan Yasal Düzenlemeler}

Yapılan analizler deneklerin yarısına yakınının $(\% 47,8)$ belge işlemlerini yürütürken referans olarak Türk Kızılayı Arşiv ve Dosyalama El Kitabını ardından deneklerin \%44,7'si Standart Dosya Planını, \%42,4'ü Türkiye Kızılay Derneği Arşiv Yönetmeliği'ni, \%30,7'si Resmi Yazışma Kuralları Hakkında Yönetmeliği kullandıklarını belirtmişlerdir. Deneklerin \%8,2'si diğer seçeneği içerisinde kalite prosedürleri vb. düzenlemeleri kullandıklarını belirtirken, \%5,2'si ise DevletArşiv Hizmetleri Hakkında Yönetmelik seçeneğini işaretlemişlerdir. Soruya yanıt veren 611 personelin \%11,1'i ise hiçbir şık işaretlemeyerek görüş bildirmemişlerdir.

Anket deneklerinin "kurumda idari ve yasal düzenlemeler iş ve işlemlerin sorunsuz biçimde yürütülmesi için yeterlidir" yargısına gruplar halinde verdikleri yanıtlar aritmetik ortalama ve standart sapma değerleri hesaplanarak Tablo 3'de verilmektedir.

Yapılan analizlerde, kurumda idari ve yasal düzenlemelerin iş ve işlemlerin sorunsuz biçimde yürütülmesi için yeteli olduğu yargısına "aynı fikirdeyim" ve "bütünüyle aynı fikirdeyim" şıklarını işaretleyen $(\% 53,6)$ şubelerin desteklediğini göstermektedir. Ardından 
\%46,6 işaretlenme yüzdesiyle lojistik birimler ve AFOM ve \%35,7 ile Genel Müdürlük birimleri bu yargıyı desteklemektedirler.

Tablo 3. Kurumda İdari ve Yasal Düzenlemelerin İş ve İşlemlerin Sorunsuz Biçimde Yürütülmesi İçin Yeterliliği

\begin{tabular}{lllllllll}
\hline & KK & K & B & A & BA & Toplam & $\Sigma$ & Sd \\
\hline Genel Müdürlük & 20 & 57 & 29 & 51 & 8 & 165 & 2,818 &, 0890 \\
$\%$ & 12,1 & 34,5 & 17,6 & 30,9 & 4,8 & 100,0 & & \\
\hline Kan Merkezleri & 36 & 75 & 48 & 54 & 14 & 227 & 2,713 &, 0777 \\
$\%$ & 15,9 & 33,0 & 21,1 & 23,8 & 6,2 & 100,0 & & \\
\hline Lojistikler ve AFOM & 2 & 13 & 24 & 30 & 4 & 73 & 3,287 &, 1076 \\
$\%$ & 2,7 & 17,8 & 32,9 & 41,1 & 5,5 & 100,0 & & \\
\hline Şubeler ve Birimler & 16 & 42 & 31 & 83 & 20 & 192 & 3,255 &, 0836 \\
$\%$ & 8,3 & 21,9 & 16,1 & 43,2 & 10,4 & 100,0 & & \\
\hline Afyon MSi & 0 & 6 & 1 & 3 & 0 & 10 & 2,700 &, 3000 \\
$\%$ &, 0 & 60,0 & 10,0 & 30,0 &, 0 & 100,0 & & \\
\hline Toplam & 74 & 193 & 133 & 221 & 46 & 667 & 2,958 & 1,157 \\
$\%$ & 11,1 & 28,9 & 19,9 & 33,1 & 6,9 & 100,0 & & \\
\hline
\end{tabular}

Grupların aritmetik ortalama değerleri incelendiğinde idari ve yasal düzenlemelerin iş ve işlemlerin sorunsuz biçimde yürütülmesine orta dereceye yakın ancak üçün altında kaldığı için hafif yetersiz olarak görüldüğü sonucu çıkmaktadır (Genel $\sum 2,958$ ). Yetersizliğe yönelik yargılar yoğunluklu olarak Afyon $\operatorname{MSi}(\Sigma 2,700)$ ve kan merkezlerinde $(\Sigma 2,713$,$) toplanmakta, ancak buralarda da ciddi sorun olarak nitelendirilebilecek iki'nin$ altında kalmamaktadır. Öte yandan şubeler ve birimler ile lojistik birimler ve AFOM'dan sağlanan yanıtların aritmetik ortalamasının üçün üzerinde olması, deneklerin sorunları bu alanlarda daha az yaşadığını göstermektedir.

\section{İdari Mekanizma İçerisinde Belgeler İşlemlerine Dönük Sorunlar}

İdari mekanizma içerisinde belgelerin resmi iletişimi sorunsuz biçimde gerçekleştirmek, yasal gereklilikleri yerine getirmek ve doğru bilgiyi sağlamak için sorunsuz biçimde kullanıldığını belirtenlerin oranı ("aynı fikirdeyim" ve "bütünüyle aynı fikirdeyim" şıklarını işaretleyen) şubeler ve bağlı birimlerde $\% 59,8$, lojistik ve AFOM birimlerinde $\% 51,4$ 'ü bulmaktadır. Bu yargııı destekleyenlerin oranı Afyon MSl'de \%60 iken Genel Müdürlük birimlerinde $\% 42$ ve kan merkezlerinde \%38,1'dir. Yargıya en olumsuz yanıtı ("kesinlikle katılmıyorum" ve "katılmıyorum" şıklarını işaretleyen) Afyon MSi (\%40) gösterirken tüm grupların olumsuz yanıtlarının 550'nin altında kaldığı dikkati çekmektedir.

Grup yanıtlarının aritmetik ortalama değerlerinin üç ile dört arasında olması yargıya kesinlik içermeyen desteğin verildiğini göstermektedir (Genel $\left.\sum 3,214\right)$. Aritmetik ortalama değerlerine göre yargıya en güçlü destek şubeler ve bağlı birimlerden $\left(\sum 3,444\right)$, en az destek ise Genel Müdürlük birimlerinden gelmiştir $\left(\sum 3,042\right)$. 


\section{Arşiv(ler)de Güncelliği Kaybolmuş Arşivlik Belgelerin Ayıklanması}

Yapılan analizler anket deneklerinin, bölümlerinde güncelliğini kaybetmiş ancak arşivlik değere sahip belgeleri, saklama sürelerinin sonunda düzenli aralıklarla ayıklama işlemine \%54,6 oranında (olumlu yanıtların genel toplamı) tabi tutuklarını, \%23,5 oranında ise ayıklama işleminin bölümlerinde yapılmadığını dile getirmişlerdir. Ayıklama işleminin düzenli olarak yürütüldüğünü dile getiren gruplar \%61,6 ile şubeler ve bağlı birimler, \%56,1 ile lojistik birimleri ve AFOM, \%54,1 ile Genel Müdürlük birimleri ve \%70 ile Afyon MSi iken, kan merkezlerinin \%50'den azı düzenli ayıklama işlemini yaptıklarını dile getirmişlerdir.

Aritmetik ortalama değerleri incelendiğinde de bütün gruplar için uygulamanın gerçekleştirilme oranı eşik değer olan üçün üzerindedir (Genel $\Sigma 3,363$ ) Ancak yargıya güçlü desteği oluşturan "bütünüyle aynı fikirdeyim" şıkkının işaretlenme oranın tüm gruplar için \%20'nin altında kalması uygulamaya ilişkin tereddütlerin de var olduğunu göstermektedir.

\section{Belge/Evrak İşlemlerinde Karşılaşılan Sorunlar}

$\mathrm{Bu}$ kısımda kurum personelinin belge ve evrak işlerinde karşılaştıkları sorunların kaynağına ilişkin betimsel istatistikler yer almaktadır.

\section{Belge Formlarından Kaynaklanan Sorunlar}

Analizler deneklerin önemli bir bölümünün belge formlarına ve yazışma kurallarına ilişkin kurum içerisinde sorun yaşanmadığını düşündüğünü göstermektedir. Belge formları ve yazışma kurallarına dönük sorun yaşayanlar en çok lojistik birimler ve AFOM birimlerinde $(\% 43,3)$ çıkarken, ardından Genel Müdürlük birimleri $(\% 38,8)$ ve Afyon MSi $(\% 33,3)$ sıralanmaktadır. Konuya ilişkin en az sorun yaşayan grup ise kan merkezleri $(\% 85,8)$ ile şubeler ve bağlı birimlerdir (\%85,7).

\section{Dosyalama İşlemlerinden Kaynaklanan Sorunlar}

Gruplar arasında belge dosyalama işlemlerinde en az sorun yaşayanlar şubeler ve bağlı birimlerdir (\%12,6), en yoğun sorun yaşayanlar ise \%37,3 ile lojistik ve AFOM birimleridir. Yine Genel Müdürlük birimlerinin \%30,3'ü dosyalama işlemlerine yönelik çeşitli düzeylerde sorunlarla karşıllaştıklarını dile getirmişlerdir. Kan merkezlerinde de dosyalama uygulamalarına ilişkin sorun yaşama oranı \%14,2'de kalmaktadır. Afyon MSl'de ise dosyalama uygulamalarında hiçbir sorun yaşamamaktadır (\%100).

\section{Belgelerin/Evrakın Dağıtım Mekanizmalarından Kaynaklanan Sorunlar}

Belgelerin dağım mekanizmasının yavaşlığından en çok lojistik ve AFOM birimleri $(\% 35,8)$, ardından kan merkezleri $(\% 32,5)$ ve Genel Müdürlük birimleri $(\% 29,6)$ şikayetçidir. Ancak bu seçeneğin işaretlenme yüzdesi tüm gruplar için \%36'nın 
altındadır. Deneklerin genel olarak \%28,5'i dağıtım mekanizmalarından şikayetçi iken $\% 71,5$ 'i ilgili konuda herhangi bir problem yaşamadıklarını ifade etmişlerdir.

\section{Belgelerin Güncel Dosyalardan Zamanında Ayıklanmamasından Kaynaklanan Sorunlar}

Belgelerin güncel dosyalardan zamanında ayıklanıp arşive gönderilmediğini dile getirenlerin yüzdesi genel toplamda 28,5 'dir. Bölümler arasında sorunu en fazla dile getirenler sırasıyla Afyon MSi $(\% 33,3)$, kan merkezleri $(\% 31,4)$, şubeler ve bağlı birimleri $(\% 29,4)$ ile Genel Müdürlük birimleri (\%25 ) personelidir. Genel toplamda deneklerin $\% 71,5$ 'i belgelerin zamanında ayıklanmasına ilişkin problem yaşamadıklarını dile getirmişlerdir.

\section{Gereksiz Belgelerin Imha Edilmemesinden Kaynaklanan Yığılmalar}

Yapılan analizler bu grupta yer alan belge işlemlerine yönelik yaşanan beş sorun içerisinde en yoğun yaşananın gereksiz belgelerin imha edilmemesi ve arşivlerde belgelerin yığılması olduğunu göstermektedir. Genel toplamda deneklerin yarıdan fazlası (\%53) ilgili konuda sorun yaşadığını dile getirmektedir. Sorunun en yoğun görüldüğü alanlar kan merkezleri (\%58), şubeler ve bağlı işletmelerdir (\%56,3). Genel Müdürlük birimlerinde de aynı sorunun yaşanması azımsanmayacak orandadır (\%48). Afyon MSl'de bu oran \%100'e çıkmaktadır. Diğer gruplara göre lojistik ve AFOM birimlerinde gereksiz belgelerin yığılmasına dönük sorun yaşama oranı \%38,8'de kalmıştır.

\section{Güncel Dosyalarda Belge Saklama Uygulaması}

Tablo 4'te halen aktif olarak kullanılan belgelerin güncel dosyalarda ne kadar süre saklandıklarına dönük betimsel istatistikler yer almaktadır.

Tabloda yer aldığı gibi, TKD birimlerinde, güncel dosyalarda bir yılını tamamlayan belgelere yönelik eşgüdümlü bir uygulama yapılmamaktadır. Belgeleri sürekli dosyalarda saklayıp herhangi bir ayıklama yapmayanların oranı tüm gruplar için \%30'un üzerinde iken, lojistikler ve AFOM birimlerinde \%49,3'e kadar çıkmaktadır. Belgeleri herhangi bir ayıklamaya tabi tutmadan topluca imha edenlerin oranı ise Genel Müdürlük birimlerinde \%0,6 çıkabilirken oran diğer gruplarda düşmektedir. Ayıklama yapmadan belgeleri olduğu gibi arşive gönderenlerin oranı Genel Müdürlük birimlerinde $\% 23$, kan merkezlerinde $\% 27,4$, lojistikler ve AFOM birimlerinde $\% 24,7$, şubelerde \%16,6 ve Afyon MSl'de \%30'dur.

Yönetmeliklere ve teamüllere uygun biçimde saklama süreleri sonunda belgeleri önem derecelerine göre ayırıp ayıklamaya tabi tutan birimlerin oranı tüm gruplar için \%40'in altında kalmaktadır. Bu uygulama en yüksek \%39,1 ile Genel Müdürlük birimlerinde yapılmaktadır. 
Tablo 4. Güncel Dosyalarda Belge Saklama Uygulaması

\begin{tabular}{lccccc}
\hline & $\begin{array}{c}\text { Genel } \\
\text { Müdürlük }\end{array}$ & $\begin{array}{c}\text { Kan } \\
\text { Merkezleri }\end{array}$ & $\begin{array}{c}\text { Lojistikler } \\
\text { ve AFOM }\end{array}$ & $\begin{array}{c}\text { Şubeler ve } \\
\text { Bağlı Birimler }\end{array}$ & Afyon MSi \\
\hline Sürekli dosyalarda & 54 & 79 & 36 & 84 & 7 \\
saklanıyor & $\% 33,5$ & $\% 36,1$ & $\% 49,3$ & $\% 44,9$ & $\% 33,5$ \\
Topluca imha & 1 & 0 & 0 & 1 & 0 \\
ediliyor & $\%, 6$ & $\%, 0$ & $\%, 0$ & $\%, 5$ & $\%, 0$ \\
Ayıklanmadan & 37 & 60 & 18 & 31 & 3 \\
arşive gönderiliyor & $\% 23,0$ & $\% 27,4$ & $\% 24,7$ & $\% 16,6$ & $\% 30,0$ \\
Saklama süreleri & 63 & 68 & 19 & 60 & 0 \\
sonunda ayıklanıyor & $\% 39,1$ & $\% 31,1$ & $\% 26,0$ & $\% 32,1$ & 0 \\
Diğer & 6 & 12 & 0 & 11 & $\%, 0$ \\
\hline Toplam & $\% 3,7$ & $\% 5,5$ & $\%, 0$ & $\% 5,9$ & 10 \\
\hline
\end{tabular}

\section{Güncel Dosyalarda Belge Ayıklama Aralığı}

Belgelerin güncel dosyalardan ayıklanma aralığına ilişkin veriler gruplar arasında farklı uygulamaların gerçekleştirilebildiğini göstermektedir. Uygulamada olması gereken belgelerin türüne göre değişen ayıklama süresini işaretleyenlerin oranı kan merkezlerinde \%55,6, Genel Müdürlük birimlerinde \%51 ve Afyon MSl'de \%56 iken diğer gruplarda \%50'nin altında kalmaktadır. Afyon MSl'de belgelerin 10 yıldan çok güncel dosyalarda tutulma oranı \%22,2'ye çıkabilmektedir (her yılın Ocak ayında güncel dosyaların ayıklamaya tabi tutulmaları gerekmektedir). Belgelerin beş yıldan çok güncel dosyalarda tutulma oranı şubelerde $\% 24,8$, Genel Müdürlük birimlerinde $\% 15,5$ 'dir.

\section{Belge Ayıklama İşleminin Kim(ler) Tarafından Yürütüldüğü}

Yapılan analizler TKD içerisindeki birimlerde belge ayıklama işleminin farklı kişi ya da komisyonlarca yürütülebildiğini göstermektedir. Tüm gruplar içinde merkezi komisyonun işaretlenme oranı \%8'in altında kalmaktadır. Birimde oluşturulan komisyonlar en çok lojistikler ve AFOM birimlerinde işaretlenirken (\%34,4), kan merkezlerinde bu oran \%15,1'e düşmektedir. Sorumlu ilgili personelce ayıklama yapıldığını dile getirenlerin oranı kan merkezlerinde \%56,1'e çıkarken bu oran Genel Merkez birimlerinde \%35,8'de kalmaktadır. Kurum dışından uzmanlarca ayıklama yapılma oranı tüm gruplar için \%2'nin altındadır.

Öte yandan "ayıklama yapılmıyor" şıkkını işaretleyenlerin oranının Afyon MSl'de $\% 44,4$, Genel Müdürlük birimlerinde \%27 ve diğer birimlerde \%20'nin üstünde çıkması dikkat çekicidir.

\section{Belge İşlemlerinde Yeniden Yapılanmaya İhtiyaç Duyulan Alanlar}

Anket deneklerinin TKD içerisinde yürütülmekte olan belge işlemlerinde yeniden yapılanmaya intiyaç duyulan alanlara ilişkin verdikleri yanıtlara ilişkin betimsel istatistikler takip eden beş alanda incelenmektedir. 


\section{Belge Üretimi ve Belge Formatlarının Yeniden Ele Alınma Gereksinimi}

Yapılan analizler kurumda belge işlemlerinin yeniden yapılanması kapsamında belge üretimine ve belge formlarının yeniden ele alınmasına ihtiyaç duyulma oranının, Afyon MSi dışında tüm gruplar için \%20'nin altında olduğunu göstermektedir. Afyon MSl'de belge işlemlerini yürüten personelin $\% 37,5$ 'i ilgili alanda yeniden yapılanma gereksinimi duymaktadır.

\section{Dosyalama Planının Yeniden Gözden Geçirilmesi}

Yapılan analizler şubeler ve bağlı birimlerin \%73,3'ü, kan merkez-lerinin \%72,4'ü Genel Müdürlük birimlerinin \%64,2'si, lojistik ve AFOM birimlerinin \%58,1'i ve Afyon MSl'nin \%75'inin dosyalama işlemlerinin yeniden yapılandırımasına gereksinim duymadığını göstermektedir. Gruplar içerisinde dosyalama işlemlerinin yeniden yapılanmasına en çok lojistik ve AFOM birimlerinde gereksinim duyulmaktadır $(\% 41,6)$.

\section{Belge Dağıtım ve İletişim Kanalları Etkinleştirilmesi}

Anket grupları arasında belge dağıtımı ve belge iletişiminin etkinleş-tirilmesine en çok lojistik ve AFOM birimlerinde gereksinim duyulduğu $(\% 31,1)$, diğer gruplarda oranın \%25'in altında kaldığı görülmektedir. Belge dağıtım ve iletişim kanallarının yavaşlığından en az şikayetçi grup Afyon MSi $(\% 12,5)$ ile şubeler ve bağlı işletmelerdir (\%16).

\section{Birimlerde Düzenli Olarak Belge Ayıklama ve Imha İşlemlerinin Gerçekleştirilmesi}

TKD'ye bağlı birimlerde düzenli olarak belge ayıklama ve imha işlemlerinin gereksinim duyma oranı \%35,7'dir. Gruplar içerisinde kan merkezlerinde yanıtların \%41,6'si, Genel Müdürlük birimlerinde \%34,6'sı, lojistik ve AFOM birimlerinin \%32,6'sı düzenli aralıklarla belge ayıklama işleminin yürütülmemesinden şikayetçi görülmektedirler.

\section{Belgelerin Elektronik Ortamda da Üretilmesi ve Kullanılması, Zamanla Elektronik Ortamın Basılı Ortamın Yerini Almasına Duyulan Gereksinim}

Anket deneklerinin "belgeler elektronik ortamda da üretilmeli ve kullanılmalı, zamanla elektronik ortam basılı ortamın yerini almalıdır" şıkkına verdikleri yanıtlar incelendiğinde, diğer şıklara oranla işaretlenme yüzdesinin daha yüksek olduğu görülmektedir. Anket deneklerinin ortalama \%58,4'ü belge işlemlerinin elektronik ortama aktarılmasına gereksinim duyduğunu ortaya koymaktadır. Bu oran kan merkezlerinde \%64,7'ye ulaşırken, Genel Müdürlük birimlerinde \%59,3'e yükselmektedir. Lojistik ve AFOM birimleri ile Afyon MSl'de oran \%50 olarak çıkmıştır. 


\section{Kurumda Mevcut Belge ve Arşiv Sistemindeki Sorunlar}

TKD içerisinde belge ve arşiv sisteminde yaşanan sorunlara ilişkin sıralanan dört alanda, anket gruplarının betimsel istatistikleri şöyle özetlenebilir:

\section{Personelin Belge ve Arşiv Uygulamalarına Dönük Yeterli Eğitiminin Olmaması}

Anket deneklerinin ortalama \%57,1'i kurumda belge işlemlerini yürüten ya da bu işlemlerde sorumluluğu olan personelin yürüttükleri işlemlere yönelik yeterli eğitime sahip olmadığını dile getirmektedir. Bu oran Afyon MSl'de \%80'e, lojistik ve AFOM birimlerinde \%74,3'e ve kan merkezlerinde \%63,2'ye çıkarken, Genel Müdürlük birimlerinde $\% 47,5$ 'de kalmaktadır.

\section{Haberleşme ve Evrak Trafiğinin Elektronik Ortamda Gerçekleştirilememesi}

Yapılan analizler haberleşme ve evrak trafiğinin elektronik ortamda gerçekleştirilmemesinin belge işlemlerinde yaşanan ciddi bir sorun olarak niteleyenlerin oranını, Genel Müdürlük birimlerinde \%60,9, lojistik ve AFOM birimlerinde \%54,1 ve kan merkezlerinde \%53,4 olduğunu göstermektedir. Şubeler ve bağlı birimlerde bu oran \%40,4'e düşerken, Afyon MSi'de \%10'da kalmaktadır.

\section{Zamanında Ayıklanamayan Belgeler Arasından Gerekli Belgelere Erişilememesi}

Anket deneklerinin zamanında ayıklanmayan belgeler arasından gerekli olanlara erişememe sorununu genel olarak \%39 oranında yaşadığı görülmektedir. Bu sorun en yoğun kan merkezlerinde $(\% 44,4)$ hissedilirken, en az Afyon MSl'de (\%20) yaşanmaktadır.

\section{E-Posta vb. Yöntemler Kullanmak Yerine Gereksiz Evrak Üretimi}

Anket deneklerinin yarısından fazlası \%52,5e-posta ya da telefonla gerçekleştirilebilecek bir işlem için gereksiz belge üretiminde şikayetçidirler. Bu sorun kan merkezlerinde $\% 64,12$ çıkarken, Afyon MSl'de $\% 60$ ve Genel Müdürlük birimlerinde $\% 56,2$ oranında görülmektedir. Lojistik ve AFOM birimlerinde ise diğer gruplardan farklı olarak sorunun görülme oranı \%28,4 çıkmıştır. Şubeler ve bağlı işletmelerde de şıkkın işaretlenme yüzdesi \%50'nin altında kalmıştır $(\% 43,9)$. 


\section{Belge İşlemlerinin Elektronik Ortama Aktarılmasına Yönelik Öncelikli Konular}

TKD içerisinde belge işlemlerinin elektronik ortama aktarılmasına öncelikle hangi nedenlerle gereksinim duyulduğu aşağıdaki beş alanda ortaya koyulmaya amacıyla çalışıımıştır:

\section{Kurum İçi Yazışmaların Intranet vb. Olanaklarla Elektronik Ortamda Yürütülmesi}

Yapılan analizler belge işlemlerini yürüten ya da bu işlemlerde sorumluluğu bulunan kurum personelinin genel olarak \%59,1 oranında, kurum içi yazışmaların elektronik ortama aktarılmasının, elektronik belge yönetimi uygulamalarına geçişte öncelikli konu olduğunu belirtmiştir. Bu oran en yüksek Genel Müdürlük birimlerinde $(\% 64,6)$, en düşük ise Afyon MSl'de (\%20) gerçekleşmiştir.

\section{Belgelerin Elektronik Ortamda Saklanması ve Korunması}

Denekler'in \%67,8'si daha güçlü şekilde elektronik belge yönetimi uygulamalarında öncelikli konular arasında belgelerin elektronik ortamda saklanmasını ve korunmasını göstermişlerdir. Genel Müdürlük, kan merkezleri, lojistik ve AFOM birimlerinden gelen yanıtların \%70'inden fazlası ilgili alanda elektronik belge yönetimi uygulamalarının gerekli olduğunu belirmektedir. Şubelerde bu oran \%53'e düşmektedir.

\section{Belgelerin Elektronik Ortamda Bibliyografik Tanımlarının Yapılması ve Erişimi}

Yapılan analizler elektronik belge yönetimi uygulamalarına geçişte belgelerin bibliyografik tanımlarının ve erişimlerinin yapılmasına, daha önceki iki uygulama kadar yoğun bir ilginin olmadığını göstermektedir. Konuya en ilgili grup Genel Müdürlük birimleridir $(\% 51,2)$. Bu oran kan merkezlerinde \%41,7'ye, lojistik ve AFOM birimlerinde \%36,1'e, şubelerde \%20,3'e ve Afyon MSl'de \%20'ye düşmektedir.

\section{Kâğıt Ortamda Üretilen Belgelerin (Bibliyografik ya da Tam Metin Olarak) Elektronik Ortama Aktarılması}

Yapılan analizler kurum personelinin genel olarak \%40,2 oranında elektronik belge yönetimi uygulamaları içerisinde basılı belgelerin elektronik ortama aktarılmasının öncelikli bir konu olduğunu dile getirmişlerdir. Bu oran kan merkezilerinde \%50’2 iken, Genel Müdürlük birimlerinde $\% 44,5$, şubeler ve bağlı birimlerde $\% 31,3$, lojistik ve AFOM birimlerinde $\% 25$ ve Afyon MSl'de \%20 olarak gerçekleşmiştir. 
Kurumsal Bilgi Sisteminde Entegrasyon Sağlamaya Dönük Olarak Idari ve Mali Yazılımlarla Belge Yönetimi Alanındaki Yazılımların Uyumluluğunun Sağlanması

Analizler doğrultusunda anket deneklerinin \%32,1'inin idari ve mali yazılımlarla belge yönetimi alanında sağlanacak yazılımların birbirleriyle uyumlu olması gerektiğini düşündüğünü göstermektedir. Bu oran tüm gruplar için yaklaşık değerlerde gerçekleşmiştir. Yargıya en güçlü destek ise Genel Müdürlük birimlerinden $(\% 37,2)$ gelmiştir.

\section{Çalışma ile Gerçekleştirilen Kapasite Değerlendirme Sisteminin Sağlayabileceği Faydalar}

Aşağıda takip eden beş alanda TKD içerisinde belge işlemlerine yönelik mevcut durumu, sorunları, beklentileri tespit etmek ve belge yönetimi uygulamalarına dönük var olan kapasiteyi değerlendirmek amaçlanmıştır.

\section{Kurumun İtiyaçları Çerçevesinde Bir Belge/Arşiv Sisteminin Oluşturulması}

Yapılan analizler anket deneklerinin kurumda gerçekleştirilen bu çalışma ile intiyaçlar ve beklentiler çerçevesinde bir belge yönetimi sisteminin oluşturulabileceğine genel toplamda \%70'in üzerinde destek verdiklerini göstermektedirler. Bu oran Genel Müdürlük birimlerinde $\% 74,4$, şubelerde $\% 71,7$, kan merkezleri, lojistik ve AFOM'da \%68 iken Afyon MSl'de \%80 olarak gerçekleşmiştir.

\section{Kurumda Farklı Uygulamaların Ortaya Çıkarılması}

Anket denekleri \%72,7 oranında işaretleme yüzdesi ile gerçekleştirilen kapasite değerlendirme analizi ile kurumda belge işlemlerine yönelik farklı uygulamaların ortaya çıkarılabileceğini düşünmektedirler. Bu oran şubelerde $\% 81,5$ 'e çıkarken, kan merkezlerinde \%75,9, Afyon MSl'de \%70, lojistikler ve AFOM birimlerinde \%63,6 ve Genel Müdürlük birimlerinde $\% 62,8$ oranında gerçekleşmiştir.

Belge ve Arşiv Uygulamalarında Standartlaşma ve Eşgüdümlülügün Sağlanması

Yapılan analizler deneklerin kapasite değerlendirme çalışmasının standartlaşma ve eşgüdümlü uygulamalara katkı sağlayacağını toplamda $\% 58,6$ oranında desteklediğini göstermektedir. Bu oran Genel Müdürlük birimlerinde \%68,3'e çıkmaktadır. Yine kan merkezlerinde denekler \%61,2 oranında yargıya destek verirken, en az desteğin şubeler ve bağlı birimlerde \%50'ye yakın oranda gerçekleştiği görülmektedir $(\% 48,4)$. 


\section{Belge ve Arşiv Uygulamalarındaki Hataların Tespiti ve Düzeltilmesi}

Kapasite değerlendirme analizi ile kurumda belge ve arşiv uygulamalarında yaşanan hatalı uygulamaların tespit edilebileceği ve gerekli düzeltme tedbirlerinin zamanında alınabileceğine dönük yargıya, anket deneklerinin toplamda \%57,7 oranında destek verdikleri görülmektedir. Bu oran Genel Müdürlük birimlerinde \%65,2'ye ulaşırken, Afyon MSl'de \%60, diğer tüm gruplarda \%50'nin üzerinde gerçekleşmiştir.

\section{Kapasite Değerlendirme Çalışmalarının Hiçbir Yarar Sağlamadığını Düşünenler}

Yapılan analizlere gore, TKD içerisinde belge işlemlerini gerçekleştiren ya da bu işlemlerde sorumluluğu olan personelin \%3,3'ü, gerçekleştirilen kapasite değerlendirme analizinin kurumda belge ve arşiv uygulamalarının geliştirilmesine hiçbir yarar sağlamayacağına inanmaktadır. Şıkkın işaretlenme yüzdesi Genel Müdürlük birimlerinde 52,4'de kalırken, lojistikler ve AFOM birimlerinde $\% 2,6$, şubeler ve bağlı birimlerde \%2,7, kan merkezlerinde \%4,5 ve Afyon MSl'de \%10'dur.

\section{Değerlendirme ve Sonuç}

TKD'de belge işlemlerine yönelik koşulları değerlendirmek üzere 679 personel (müdür, birim yöneticisi, uzman, asistan, sekreter, doktor, hemşire, tercüman, mühendis, mimar, tekniker, kontrolör, tıbbi sekreter,şube başkanı, hizmetli) üzerinden gerçekleştirilen anket uygulamasında aşağıdaki sonuçlara ulaşılmıştır.

Kurumun Türkiye çapında gönderilen tüm birimlerinden sağlanan anket verileri doğrultusunda toplam 2454 personelin 258'inin bir başka deyişle \%10,51'inin belge/ arşiv personeli olduğu görülmektedir. Kurumda 2006 yılı sonu itibariyle bir yıl içerisinde (her yılsonunda giden ve gelen evrak defterleri yenilendiğinden yılsonunda verilen son sayılar aynı zamanda bir yılda üretilen ya da sağlanan belge sayılarını ortaya koymaktadır) kurumun çeşitli birimlerine gelen belge sayısı 109,063 ve birimlerden çıkış yapan belge sayısı 97,315'dir. Bu durumda anket verileri doğrultusunda TKD'de 2006 yılında toplam 206,378 adetlik bir belge birikimi olduğu ortaya çıkmaktadır. Anket verileri sonucunda 16 ayrı kan merkezinde toplam 20,935 adetlik belge birikimi olurken tek başına İnsan Kaynakları Müdürlüğünde 27,699 adetlik, Haberleşme ve Arşiv Müdürlüğünde ise 45,684 adetlik belge birikimi olmuştur.

TKD içerisinde belge işlemlerini yürüten personelin çalışma sürelerine bakıldığında tüm gruplarda ilk sırada 5 yıldan az çalışan personelin yer aldığı görülmektedir. Aritmetik ortalama değerleri doğrultusunda gruplar arasında en genç personele kan merkezileri $(\Sigma 1,864)$ ile lojistik ve AFOM personelinin $\left(\sum 1,897\right)$ sahip olduğu ortaya çıkmaktadır.

Yapılan analizler belge işlemlerini yürüten personelin ağırlıklı olarak uzman ve asistanlardan oluştuğunu göstermektedir $(\% 63,5)$. Belge işlemlerini yürütenler arasında sekreterlerinin oranı ise $\% 2,1$ 'de kalmaktadır. Ankete yanıt veren deneklerin yaklaşık 
beşte biri $(\% 19,4)$ ise belge işlemlerine yönelik yönetici pozisyonundaki personelden oluşmaktadır. Bu sonuçlardan ankete yanıt veren deneklerin yaklaşık \%80'inin bu işlemlerin yürütülmesinden, \%20'sinin ise belge işlemlerinin yönetiminden sorumlu olduğu ortaya çıkmaktadır.

Anket deneklerinin önemli bir bölümü $(\% 91,5)$ belge işlemlerini yürüten ya da bu işlemlerden sorumlu personelden oluşmaktadır. Ancak bu personelin oldukça düşük bir kesimi (\%21) ilgili okuldan mezun olarak ya da çeşitli düzeyde kurs ya da seminer aktivitelerine katıldıklarını dile getirmişlerdir. Geriye kalan yaklaşık dörtte üçü ise yürüttükleri belge uygulamalarını kendi çabalarıyla öğrendiklerini ya da herhangi bir bilgilerinin olmadığını ifade etmişlerdir. Bu durum kurum içerisinde belge ve arşiv uygulamalarına dönük eğitim çalışmalarına duyulan gereksinimin boyutlarını göstermesi bakımından önemli görülmektedir.

Personelin yürüttüğü belge işlemlerine yönelik eğitim verileri ayrıntılarıyla incelendiğinde, ihtiyacın şubelerde, kan merkezlerinde, lojistik ve AFOM birimlerinde daha fazla olduğu, Genel Müdürlük birimlerinin eğitim konusunda daha iyi konumda bulunduğu ortaya çıkmaktadır.

Anket deneklerinin çok büyük bir kesimi belgeleri günlük işlerinde yoğun biçimde kullanmaktadırlar. Toplamda deneklerin \%73,8'u günde iki saatten çok belge işlemleriyle uğraştığını dile getirmektedir. Belgelerle işi olmadığını dile getiren personelin oranı yalnızca \%1,8'dir. Gruplar arasında belge işlemleri en yoğun birim Genel Müdürlük birimleri iken nispeten şubelerin belge işlemlerine dönük yükü daha azdır. Kan merkezlerindeki yoğunluk ise Genel Müdürlüğün hemen ardından gelmektedir.

Personel belge türü olarak en çok raporlara $(\% 40,4)$ zaman harcamakta, ardından form türü belgeler $(\% 38,8)$, yazışmalar $(\% 34)$ ve talimatlar $(\% 23,9)$ sıralanmaktadır. Bu belge türleri kurumdaki toplam belge yükünün \%97,3'ünü oluşturmaktadır.

Belge işlemlerinin oluşum nedenleri incelendiğinde iki konu ön plana çıkmaktadır. Bunlardan ilki kurumsal uygulamaların gerçekleştirilmesi ve diğer kuramlarla iletişimin sağlanmasıdır. Bu konular \%70'in üzerinde bir işaretlenme yüzdesine sahiptir. Belge üretim nedenleri arasında denetim ve kontrol faaliyetleri \%26,1'de kalmaktadır. Bu sonuçlar kurumsal işlemler ve iletişim faaliyetlerinin toplam belge yükünün \%80'ine yakınını, denetim ve kontrol faaliyetlerinin de \%20'sine yakınını oluşturduğunu ortaya koymaktadır.

Kurum personeli belge işlemlerini yürütürken $\% 47,8$ oranında TKD Dosyalama ve Arşiv El Kitabını kullanmaktadır ki; bu oranın \%50'nin altında kalması yetersiz görülmelidir. Diğer şıklarda verilen yasal düzenlemeler ve kurumdaki Standart Dosya Planı uygulamasının da işaretlenme yüzdeleri \%50'nin altındadır. Bu durum kurumda belge işlemlerini yürüten ya da bu işlemlerde sorumluluğu olan personelin yürüttükleri işlemleri belirleyen yasal koşullar konusunda yeterince bilinçli olmadıklarını göstermektedir. 
Anket deneklerinin kurum içerisinde idari yapılanma ve belge işlemlerine hangi alanlarda ne oranda sorun yaşadıklarını belirlemeyi amaçlayan, birbirini takip eden altı soruya verilen yanıtlar değerlendirildiğinde en sorunlu alanın çalışanların kendi aralarındaki uyum ve eşgüdüm problemi olduğu görülmektedir (Genel $\Sigma 2,888$ ). Bu durum kurumun birimleri arasında belge işlemlerine yönelik farklı uygulamaların olmasından kaynaklanmaktadır. Kurum tarafından oluşturulan arşiv yönetmeliğinin, Türk Kızılayı Arşiv ve Dosyalama El Kitabının ve uygulama örneklerinin kurumun tüm birimleri tarafından aynı titizlikle takip edilmemesinin bu tür farklı uygulamalara yol açtığı düşünülmektedir. Saptamayı destekleyen önemli bir veri olarak; "idari mekanizma içerisinde belgeler; resmi iletişimi sorunsuz biçimde gerçekleştirmek, yasal gereklilikleri yerine getirmek ve doğru bilgiyi sağlamak için kullanılmaktadır" ifadesini deneklerin daha yoğun biçimde desteklemesi $\left(\sum 3,200\right)$ gösterilebilir. Bu durum kurum içerisinde belge işlemlerine yönelik geliştirilen düzenlemelerin daha geniş bir kesim tarafından anlaşılabilmesi için çeşitli eğitim faaliyetlerin yürütülmesi gerektiğini ortaya koymaktadır.

Kurum personeli kurumda daha önce üretilmiş belgelere erişim araçları olarak en çok $(\% 64,1)$ evrak kayıt defterleri ve indekslerden yararlanmaktadır. Ancak belge dosyalarının doğrudan taranması da en az erişim araçları kadar $(\% 60,5)$ kullanılan bir yöntemdir. Belgelere ulaşmada ilk olarak erişim araçlarının kullanılmasının erişimi hızlandırma ve zaman kaybını önleme gibi önemli bir yararı vardır. Sonuçlardan, kurum içerisinde belge erişim araçları olarak evrak kayıt defterlerinin her birim tarafından titizlikle tutuluyor olması önemli görülmektedir. Öte yandan deneklerin yalnızca \%30'u elektronik ortamda kayıtlardan belgelere erişimi sağladıklarını belirtmişlerdir. Bilindiği gibi kurumda elektronik belge yönetimi uygulamalarında öncelik, kayıt defterlerinin ve diğer erişim araçları olarak indekslerin elektronik ortama aktarılması, böylece basılı da olsa belgelere ait kimlik ve yerleşim bilgilerinin elektronik ortamda tutulması olmalıdır. Kurum personelinin \%43,5'i diğer personelden yardım alarak gereksinim duydukları belgelere eriştiklerini dile getirmişlerdir. Ancak kişilere bağlı olarak yürütülen işlemlerde sürekliliğin sağlanamayabileceği bunun için indeksler, elektronik indeksler, envanterler, kataloglar gibi sistematik erişim araçlarının geliştirilmesi ve yaygınlaştırılması gerektiği düşünülmektedir.

Kurumda belge işlemlerinde görev alan personel, çalışmalarında en çok gereksiz belgelerin imha edilmemesinden şikâyet etmektedirler. İmha işlemi uygulanmayan ve depolama alanlarında giderek biriken belgeler, gerekli olanların erişiminde de en büyük engeli teşkil etmektedirler. Bu sorun tüm gruplar için öncelik teşkil etmekle birlikte, kan merkezlerinden gelen yanıtların \%58'inde, şubelerden gelenlerin \%56,3'ünde, Afyon MSl'den gelenlerin de tamamında bu sorun üzerinde daha çok durulmaktadır. Öte yandan lojistikler ve bağlı birimlerin \%35'inde görülen belge dağıtım mekanizmalarının yavaşlığından kaynaklanan sorunlar ve Genel Merkez birimlerinin \%30,3 oranında işaretlediği dosyalama uygulamalarından kaynaklanan sorunlar kurumsal belge sisteminin düzenlenmesinde göz önünde bulundurulmalıdır. 
Kurumda belge erişim sorunlarının ne ölçüde yaşandığını, aranan belgelere ulaşmak için kurum personelinin ne kadar mesai harcadığını belirlemeye dönük soruya verilen yanıtlar, anket gruplarının belge erişimine günlük ortalama 45 dakikadan çok zaman harcama oranının \%27,9 olduğunu göstermektedir. Gruplar arasında kan merkezlerinde günde ortalama aranan belgelere erişmek için 45 dakikadan zaman harcama oranı \%30'un üzerine çıkmaktadır. Genel Müdürlük birimlerinde bu oran \%27'dir. Bu oranların aşağılara çekilmesi ile kurum içerisinde belgelere erişmek için harcanan sürenin daha rasyonel kullanılması mümkün olabilecektir.

TKD içerisinde üretilen belgelerin arşive kaldırılmadan önce ofis ortamlarında saklama uygulamalarını belirlemek için oluşturulan soruya verilen yanıtlar kurum içerisinde farklı uygulamaların söz konusu olduğunu göstermektedir. Kan merkezlerinden alınan yanıtların \%36'sı belgelerin arşive gönderilmeden sürekli saklandığı, lojistik ve AFOM'dan sağlanan yanıtların \%24,7'si ayıklanmadan arşive gönderildiği, Genel Müdürlük birimlerinin yanıtların \%39,1'i de saklama sürelerinin sonunda ayıklandığı yönündedir. "Türk Kızılayı Arşiv ve Dosyalama El Kitabı"na göre doğru uygulama; belgelerin saklama sürelerinin sonunda ayıklanıp gereksiz olanlar ayıklandıktan sonra gerekli belgelerin arşive gönderilmesidir. Bu uygulamayı gruplar arasında en çok Genel Müdürlük birimleri $(\% 39,1)$ işaretlemiştir. Sonuçlardan kurum içerisinde güncel dosyalardan belgelerin ayıklanarak arşive gönderilmesi konusunda sorunlar yaşandığı ortaya çıkmaktadır.

Güncel dosyalardan hangi sürelerde ayıklama işleminin yapıldığını sorguladığımızda, ağılıklı uygulamanın $(\% 55,6)$ belge türüne göre değiştiği sonucu çıkmıştır. Bu uygulama TKD belge saklama planı ile uyumludur. Ancak lojistikler ve AFOM, şubeler ve bağlı işletmeler ile Afyon MSl'de uygulamanın işaretlenme oranı \%50'nin altında kalmaktadır. Bu durum kurumda belge saklama planları geliştirilmiş ve konuya ilişkin el kitabı hazırlanmış olmasına karşın uygulamada sorunlar yaşandığını, birimlerde ayıklama çalışmalarının yürütülmesi konusunda uygulamaya dönük çalışmalara ağırlık verilmesi gerektiğini ortaya koymaktadır.

TKD içerisinde ayıklama uygulamasının kimler tarafından yürütüldüğünü belirlemeye dönük soruya verilen yanıtlara gore, TKD içerisinde oluşturulan merkezi komisyonlarca ayıklama imha çalışmalarının yapılma oranının tüm gruplarda \%8'in altında kaldığını göstermektedir. Ağırlıklı uygulama birimlerde oluşturulan komisyonlar ve sorumlu personel tarafından belgelerin ayıklanması şeklindedir. Öte yandan Genel Müdürlük birimlerinden alınan yanıtların \%27'si, kan merkezilerinin \%21'i, lojistik ve AFOM'un \%20,3'ü ile şubelerin \%23,6'sı birimlerinde ayıklama ve imha yapılmadığını dile getirmektedir. Belge yönetimi uygulamalarında yaşanan sorunların başlıca nedenleri arasında yer alan bu sorunun giderilmesine yönelik adımların atılması gerekli görülmektedir.

TKD içerisinde belge işlemlerini yürüten ya da bu işlemlerde sorumluluğu olan personel, kurumsal belge yönetimi uygulamalarının yeniden yapılandırılmasında en öncelikli alanı, \%58,4 oranında belge işlemlerinin elektronik ortama taşınmasında görmektedir. Bu oran Genel Müdürlük birimleri ve kan merkezlerinde diğer birimlere 
göre daha da yükselmektedir. İkinci öncelikli alan, birimlerde belge ayıklama ve imha işlemlerinin düzenli olarak yürütülmesi işlemi, tüm gruplarda \%35'in üzerinde işaretlenme yüzdesiyle gelmektedir. Dosyalama uygulamalarında yaşanan problemlere karşı önlemlerin alınma gereksinimi, genel ortalamada \%30'un üzerinde işaretlenme oranıyla üçüncü sıradadır. Bu sonuçlar kurum personelinin belge işlemlerine yönelik çeşitli düzeylerde sorunlar yaşadığını, ancak işlemlerin yeniden yapılandırılmasında elektronik belge yönetimi uygulamalarına geçişin öncelikli olarak gördüğünü ortaya koymaktadır.

Kurumda belge ve arşiv uygulamalarını gerçekleştiren anket deneklerinin ortalama \%57.1'i personelin belge ve arşiv uygulamalarına yönelik yeterli eğitimi olmadığını dile getirmektedir. Bu oran Genel Müdürlük birimlerinde \%47,5'e düşerken, lojistik ve AFOM birimlerinde \%74,3'e, Afyon MSl'de ise \%80'e çıkmıştır. Belge işlemlerini yürüten personelin önemli birçoğunluğunun yürüttükleri belge işlemleri konusunda yeterli eğitimi almadıklarını dile getirmeleri üzerinde önemle durulması gereken bir konuyu oluşturmaktadır.

Anket deneklerinin ortalama \%50'den çoğu kurumsal haberleşme trafiğinin elektronik ortamda gerçekleşmemesinin işlemleri yavaşlattığını dile getirmektedirler. Bu oran Genel Müdürlük birimlerinde \%60,9'dur. Kan merkezilerinin de $\% 53,4$ 'ü aynı konu üzerinde durmaktadır. Bu sonuçlardan elektronik belge yönetimi uygulamalarında öncelikli olarak kurum için rutin yazışma ve talimat trafiğinin elektronik ortama aktarılması gerektiği düşünülmektedir.

Kurum içerisinde belge işlemlerinin elektronik ortama aktarılması konusunda öncelikli alanlar arasında, kurum içi yazışmaların İntranet vb. olanaklarla elektronik ortama aktarımasının \%59,1 ile ilk sırada gösterilmesi bu savı destekleyen bir başka veriyi oluşturmaktadır. Bu oran Genel Müdürlük birimlerinde \%64,6’ya kadar çıkmaktadır.

Kurum personelinin \%67,8'i elektronik ortamı belgelerin saklanması ve korunması için elverişli bir alan olarak görmektedir. Yine Genel Müdürlük birimleri \%74,4'lük işaretleme oranıyla elektronik belge yönetimi uygulamalarının bir parçası olarak elektronik ortamda belge saklama ve korumaya geçişe en istekli grubu oluşturmaktadır. Şubelerde oran \%53'e düşerken diğer gruplarda \%70'in üzerindedir.

Elektronik belge uygulamalarına geçişte belgelerin elektronik ortamda bibliyografik tanımlamalarının yapılmasını Genel Müdürlük birimlerinin \%51,2'si önemli görürken, diğer birimlerde bu oran \%50'nin altında kalmaktadır.

Yapılan analizler basılı belgelerin elektronik ortama aktarılmasının elektronik belge yönetimi uygulamalarına geçişte önceki üç seçeneğin ardından önemli görüldüğünü göstermektedir (\%40,2). Uygulamada da ciddi maliyet yükü getirecek, hâlihazırda üretilmiş ve saklanan belgelerin elektronik ortama aktarılmasının öncelikli olarak değerlendirilmemesi gerekli görülmektedir. Ancak önem taşıyan ve kaybı kurumsal uygulamaları sekteye uğratacak nitelikteki kayıtların öncelikli olarak elektronik ortamda saklanması ve korunması gerçekleştirilmelidir. 
Elektronik belge yönetimi uygulamalarına geçişte bir diğer önemli konu, diğer yazılım programları ile belge yönetimi programlarının tek bir yönetim bilgi sistemi içerisinde tanımlanmasıdır. Kurum personelinin \%32,1'i idari, mali işler, personel ya da teknik hizmetler alanında kurumda uygulanmakta olan yazılım programları ile elektronik belge yönetimi yazılımlarının bütünleştirilmesini öncelikli konu olarak görmektedir.

TKD içerisinde gerçekleştirilen kapasite değerlendirme çalışmasıyla, kurumun intiyaçları çerçevesinde bir belge ve arşiv sisteminin oluşturulabileceğine dönük yargıya anket deneklerinin ortalama \%71.1'i destek vermişledir. Bu oran Genel Müdürlük birimlerinde \%74,4'e, şubeler ve bağlı işletmelerde \%71,7'ye, Afyon MSl'de \%80'e çıkmaktadır. Tüm gruplarda oranlar \%68'in üzerinde gerçekleşmiştir. Bu sonuç çalışmanın hipotezinde yer alan unsurları desteklemesi bakımında önemli görülmektedir.

Kapasite değerlendirme çalışmasıyla, kurumda farklı uygulamaların ortaya çıkarılabileceğine dönük yargıya grupların desteği ortalamada \%72,7 olmuştur. Bu yargıyı destekleyenlerin oranı şubeler ve bağlı işletmelerde \%81,5’e çıkmaktadır. Tüm gruplarda destek \%60'ın üzerindedir.

Kapasite değerlendirme analizinin kurumda belge ve arşiv uygulamalarında standartlaşma ve eşgüdümün sağlanmasına katkı yapacağına dönük yargıya denekler ortalama \%58,6 oranında destek vermişlerdir. Bu oran Genel Müdürlük birimlerinde $\% 68,3$ 'e çıkmaktadır.

Kapasite değerlendirme analizinin belge ve arşiv uygulamalarında hataların tespiti ve düzeltilmesine katkısına yönelik yargıya deneklerin ortalama \%57,7'si destek vermişlerdir. Bu oran Genel Müdürlük birimlerinde \%65,2'ye, Afyon MSl'de \%60'a, kan merkezlerinde \%56,3'e çıkmaktadır.

Kapasite değerlendirme analizinin, kurumda belge ve arşiv uygulamalarının iyileştirilmesine hiçbir katkı sağlamayacağı seçeneğinin işaretlenme oranı \%3,3'de kalmıştır. Bu oran tüm gruplarda \%5'in altında kalmıştır. Bu sonuç TKD'de belge işlemlerini yürüten ya da bu işlemlerde sorumluluğu olan personelin, "Türkiye Kızılay Derneği örneğinde kurumlarda belge yönetimi sistemleri geliştirilirken kapasite değerlendirme çalışmalarının yapılmasına gereksinim vardır" şeklindeki hipoteze \%95'in üzerinde bir oranda destek verdiğini göstermektedir. Bu çerçevede "Türkiye Kızılay Derneği'nde belge yönetimi uygulamalarının geliştirilebilmesi için kapasite değerlendirme çalışmasının yapılmasına gereksinim vardır" şeklindeki hipotez de, TKD içerisinde belge işlemlerinde görevli ya da belgeleri kullanan personelin \%95'in üzerinde desteğiyle kanıtlanmıştır.

\section{Öneriler}

Gerçekleştirilen ankete ilişkin bulguların değerlendirilmesi sonucu, TKD içerisinde iyileştirilmesi gerekli görülen unsurlara ilişkin öneriler aşağıda yer almaktadır.

1. TKD içerisinde var olan bilgi ve belge sisteminin uluslararası standartlar, düzenlemeler ve uygulama örnekleri göz önüne alınarak tekrar değerlendirilmesinde yarar görülmektedir. 
2. TKD içerisinde uygulamaya konulan standart dosya planı, belge saklama ve imha planı, belge ve arşiv işlemlerine yönelik yönetmelik, belge yönetimi el kitabı, arşiv projesi ve uygulamaları, kurumun belge ve arşiv çalışmalarına verdiği önemi göstermektedir. Bu uygulamaların gözden geçirilmesi ve sistematiğe kavuşturulması ile kurum için son derece önemli olan haberleşme ve arşiv çalışmalarının daha da etkinleşebileceği göz önünde tutulmalıdır.

3. Gerçekleştirilen anket uygulaması toplam kurum personelinin yaklaşık \%10'unun belge işlemlerinden sorumlu olduğu ve bu personelin iş yükünün genellikle kurum içerisinde dengeli dağılım gösterdiğini ortaya koymaktadır. Ancak Haberleşme ve Arşiv Müdürlüğü ile İnsan Kaynakları Müdürlüğü'nün belge işlemlerine yönelik iş yükü diğer birimlere göre çok daha yoğun görülmektedir. İlgili birimlerde belge işlemlerine yönelik iş yükünün hafifletilmesi konusunda önlemlerin alınması yararlı olacaktır.

4. Anket sonuçları TKD içerisinde belge işlemlerini yürüten personel için daha sistematik ve yoğun eğitim faaliyetlerine gereksinim olduğunu ortaya koymaktadır. Bu çerçevede belge işlemlerine yönelik eğitim faaliyetlerinin Genel Müdürlük dışındaki birimleri de kapsayacak biçimde yaygınlaştırılmasında yarar görülmektedir.

5. Aynı uygulamaya dönük farklı birimlerde ayrı uygulamaların yapılmasından kaynaklanan sorunun giderilmesi konusunda çaba gösterilmesi gerekmektedir.

6. Kurum içerisinde belge erişim aracı olarak kullanılan gelen ve giden evrak defterlerinin belge işlemlerinin yürütüldüğü tüm birimlerde titizlikle tutulması sağlanmalıdır. TKD içerisinde belge erişiminin kayıt defterleri ve doğrudan klasörlerin taranması dışında elektronik ortamda hazırlanacak envanter ya da indeksler yardımıyla da yapılması konusunda çalışmalar başlatılmalıdır. $\mathrm{Bu}$ kapsamda uygulamada yaşanabilecek yoğunluk ve personel eksikliği düşünülerek, öncelikli olarak kayıt defterlerin elektronik ortama aktarılması, giden ve gelen evrak takibinin elektronik ortamda yürütülmesi uygulamasına geçilmesinde yarar görülmektedir.

7. Kurum içerisinde belgelerin zamanında ayıklanmaması ciddi bir sorun olarak görülmektedir. Belge ayıklama işlemlerinin kuruma ait tüm birimlerde ayıklama ve imha planlarında öngörüldüğü gibi gerçekleşmesi için çabaların artırılması gerekmektedir. Belgelerin imhası konusunda tedirginlik yaşayan, önemli belgeler arasından önemsiz olanların saptanmasının zor olduğu alanlarda ayıklama işlemlerinin düzenli olarak yürütülmesine dönük merkezi ayıklama ve imha komisyonu çalışmalarının yaygınlaştırılması gerekmektedir.

8. Elde edilen sonuçlar personelin belge erişimine mesaisinin önemli bir bölümünü ayırdığını göstermektedir. Kurumda belge erişim problemlerinin giderilmesinde düzenli ayıklama işlemlerinin yürütülmesi ve erişim araçlarının çeşitlendirilmesi kadar depolama ve depoların yerleşiminin de önemli olduğu görülmektedir. Bu 
noktada ulusal ve uluslararası uygulama örnekleri çerçevesinde; güncelliğini koruyan belgelerin üretimden itibaren ilk yıl ofis ortamlarında tutulması, bir yılın sonunda ayıklanan belgelerin, takip eden beş ya da belge türüne göre 10 yıl ofis ortamlarından erişimin rahat olduğu ara depolarda muhafaza edilmesi ve ardından kullanım değeri taşıyan belgelerin merkezi arşivlere kaldırılması gerekmektedir. Kurum içi düzenlemelerde öngörülen bu uygulamalara ilişkin gerekli alanların tanımlanması, yerleşim planlarının erişime elverişli biçimde oluşturulması ve ilgili tüm birimlerde aynı titizlikte uygulanmasına dönük çalışmaların yoğunlaştırılması gerekmektedir.

9. TKD içerisinde belge işlemlerinin elektronik ortama aktarılması başta Genel Müdürlük birimleri olmaküzere kurum personelinin öncelikli gördüğü alanlardan birini oluşturmaktadır. Belge işlemlerinin elektronik ortama aktarılması aşama aşama düşünülmesi gereken bir konu olarak görülmelidir. Öncelikle belge kayıt defterlerinin ve erişim bilgilerini içeren envanterlerin, ardından kurum içerisinde rutin haberleşme ve talimat zincirinin kurum içi yerel ağ aracılığıyla ve gerekli yazılım olanakları sağlanarak elektronik ortama taşınması, sonrasında hayati önem taşıyan belgelerden başlayarak elektronik ortama aktarılması gerekli görülmektedir. Elektronik belge yönetimi programları gelecek gereksinimlerini karşılamaya dönük modüler kullanıma uygun, çok yönlü ve tanımlanmış düzeylerde erişime olanak tanıyan bir yapıda olmalıdır. Kurum içerisinde tüm bilgi ve belge işlemlerinin elektronik ortama taşınması, bu çerçevede gerekli sayısal sertifikaların ve dijital imza gerekliliklerinin karşılanması önemlidir. Başlangıç aşamasında elektronik uygulamalar yanında basılı belge uygulamalarının bir süre birlikte yürütülmesinde yarar görülmektedir.

10. TKD personeli kurum içerisinde belge işlemlerine yönelik mevcut koşulları tanımlamaya dönük gerçekleştirilen kapasite değerlendirme analizlerini; ulusal ve uluslararası koşullar doğrultusunda kurumsal intiyaçları göz önüne alarak var olan belge ve arşiv sisteminin geliştirilmesi, kurumdaki farklı uygulamaların açığa çıkarılması, eşgüdümlü uygulamalara gidilmesi açısından yararlı görmektedir. Gerçekleştirilen bu çalışmaların periyodik aralıklarla yapılması ve işlemlerde sürekliliğin sağlanması gerekli görülmektedir.

\section{Kaynakça}

Ayıklama ve imha komisyonlarina ait çalışma rehberi ve devlet arşivlerine arşivlerin devir işlemleri: 3473 sayılı Muhafazasına Lüzum Kalmayan Evrak ve Malzemenin Yok Edilmesi Hakkında Kanun kapsamında yer alan kurum ve kuruluşlarda. (1996). Selvet Saraç ve Mehmet Torunlar (Yay. Haz.). Ankara: Devlet Arşivleri Genel Müdürlüğü Cumhuriyet Arşivleri Daire Başkanlığı.

Baş, T. (2001). Anket: Anket nasıl hazırlanır, anket nasıl uygulanır, anket nasıl değerlendirilir? Ankara: Seçkin.

Bilgi Edinme Hakkı Kanunu. (2003). Resmî Gazete, Sayı: 25269, 24 Ekim 2003. 
Cisco, S. L. ve Strong, K. V. (1999). The value added information chain. Information Management Journal, 33(1), 4-15.

Çiçek, N. (2000). ISO 9000 kalite güvence sistemi standardında evrak üretimi ve yönetimi. Arşiv Araştırmaları Dergisi, 2, 7-34.

Devlet Arşiv Hizmetleri Hakkında Yönetmelik. (1988). Resmî Gazete, Sayı: 19816, 16 Mayıs 1988.

Devlet Arşiv Hizmetleri Hakkında Yönetmelikte Değişiklik Yapılmasına Dair Yönetmelik. (2001). T.C.Resmi Gazete, Sayı: 24487, 08 Ağustos 2001: 95-100.

Dollar, C. M. (2002). Authentic electronic records: Strategies for long term access. Chicago: Cohasset Association.

Elektronik İmza Kanunu. (2004). Resmî Gazete, Sayı: 25355, 23 Ocak 2004.

Gürbüz, S. (1990). Belge erişiminde teknolojik yaklaşım. Yayımlanmamış doktora tezi, Hacettepe Üniversitesi, Ankara.

Information management planning. (2005). Government of Alberta Information Management Branch. 3 Eylül 2007 tarihinde http://www.im.gov.ab.ca/publications/pdf/IMPlanningGuide.pdf adresinden erişildi.

İçimsoy, A. O. (1999). Arşivlerde mikroform kullanımı: Yeni teknolojiler ve sorunlar. Bilgi Çağı, Bilgi Merkezleri ve Bilgi Teknolojileri Sempozyumu 7-9 Mayıs 1997 - Bildiriler içinde (ss.7-14). Ankara: Ankara Üniversitesi.

Kandur, H. (1998). Arşivlerde kullanıcı hizmetleri ve bilgisayar kullanımı. I.Milli Arşiv Şurası (TebliğlerTartışmalar) <20-21 Nisan 1998 Ankara> içinde (ss.579-588). Ankara: Başbakanlık Devlet Arşivleri Genel Müdürlüğü.

Kandur, H. (2006). Elektronik belge yönetimi sistem kriterleri referans modeli. İstanbul: Devlet Arşivleri Genel Müdürlüğü. 1 Haziran 2007 tarihinde http://www.devletarsivleri.gov.tr/EBYS_v_2_0.pdf adresinden erişildi.

Kaptan, S. (1989). Bilimsel araştırma ve gözlem teknikleri. Ankara: Tekışık Matbaası.

Külcü, Ö. (2005). Kamu üniversitelerinde kalite yönetimi ve kalite sistem dokümantasyonu çerçevesinde belge yönetimi. Yayımlanmamış doktora tezi, Hacettepe Üniversitesi, Ankara.

Odabaş, H. (2007). Elektronik belge yönetimi ve kamu kurum ve kuruluşları. Yayımlanmamış doktora tezi, Ankara Üniversitesi, Ankara.

Özdemirci, F. (1996). Kurum ve kuruluşlarda belge üretiminin denetimi ve belge yönetimi. İstanbul: Türk Kütüphaneciler Derneği İstanbul Şubesi.

Pember, M. (2006). Sorting out the standards: What every records and information professional should know. Records Management Journal, 16(1), 21-31.

Penn, I. A., Mordel, A. ve Pennix, G. (1994). Record management handbook. Kelvin Smith: Gower. 
Shepherd, E. ve Geoffrey, Y. (2003). Managing records a handbook of principles and practices. London: Facet Publishing.

Spratt, R. (2004). Records management: The next ten years. RDIMS (Records, Documents and Image Management Systems). Canadian Federal Government Shared System Initiative. 8 Haziran 2006 tarihinde https://www.rdims.com/Documents/WhitePaper-RecordsManagementTheNextTenYears.doc adresinden erişildi.

Standart Dosya Planı. (2005). Başbakanlık Personel ve Prensipler Genel Müdürlüğü Genelge, Sayı: 320-3802, 24 Mart 2005.

T.C. Başbakanlık Devlet Planlama Teşkilatı. (2008). Kalkınma planları. 18 Haziran 2008 tarihinde http:// ekutup.dpt.gov.tr/plan.asp adresinden erişildi.

TS ISO 15489-1. (2007). Bilgi ve dokümantasyon - Belge yönetimi Bölüm 1: Genel. Türk Standartlar Örgütü: Ankara.

TS ISO 15489-2. (2007). Bilgi ve dokümantasyon - Belge yönetimi - Bölüm 2: Kılavuzlar. Türk Standartlar Örgütü: Ankara.

Türk Standartları Enstitüsü. (2007a). Bilgi ve dokümantasyon - Belge yönetimi (TSE ISO 15589-1). 1 Kasım 2007 tarihinde https://www.tse.org.tr/turkish/abone/StandardDetay. asp?STDNO=45399\&sira $=0$ adresinden erişildi.

Türk Standartları Enstitüsü. (2007b). Bilgi ve dokümantasyon - Elektronik belge yönetimi. (TSE 13298). 1 Kasım 2007 tarihinde http://www.tse.org.tr/Turkish/Abone/Standard_Ara.asp?Durum=IcsTablo su\&Sira $=1 \&$ EskiKod=01.110 adresinden erişildi.

Williams, R. F. (2002). Realizing the need and putting the key components in place to getting it right in records management. Maryland: AllM International.

Zawiyah, M. Y ve Chell, R. W. (2002). Towards a theoretical construct for records management. Records Management Journal, 12(2), 55-64. 